$>\sim 200 \mathrm{~m}$, except over the built-up regions in the domain where blt is still shallow, which is highly conditioned by UHI effect. The effect of Cartosat-1 in VI forecast is visible in Figure $6 c$, except that the southern ridge dipole nature of index is visible in the nearby grids and majority of the grid points in the domain give reduced values in VI forecast.

In summary, the use of Cartosat-1 satellite DEM to generate orography for the DM model and its impact on the model forecast of fog/visibility-related parameters are examined. The effect of Cartosat-1 DEM through changes in the mean orography is felt at the lowest boundary layer through enhanced downdraft, and the associated push down of the boundary. In addition, the surface winds are weakened in most areas, though they are highly variable and turbulent in nature. Histogram analysis revealed enhanced fog growth through the formation of shallow boundary layer and reduced surface wind speed in the Cartosat-run. The Cartosat orography has been operationalized in the DM model since the winter season of 2018 . Besides the daily operational fog/visibility forecast, the forecasting of VI from DM can serve as a potential proxy for short-range air-quality monitoring. The results presented here could be beneficial to improved air-quality risk monitoring, management and strategic planning, especially over the Delhi region.

1. Ghude, S. D., Bhat, G. S., Prabhakaran, T., Jenamani, R. K., Chate, D. M., Safai, P. D. and Rajeevan, M., Winter fog experiment over the Indo-Gangetic plains of India. Curr. Sci., 2017, 112, 767-784.

2. Gautam, R. and Singh, M. K., Urban Heat Island over Delhi punches holes in widespread fog in the Indo-Gangetic Plains. Geophys. Res. Lett., 2018, 45; https://doi.org/10.1002/2017GL076794.

3. Boutle, I. A., Price, J., Kudzotsa, I., Kokkola, H. and Romakkaniemi, S., Aerosol-fog interaction and the transition to well-mixed radiation fog, Atmos. Chem. Phys., 2018, 18, 7827-7840; https://doi. org/10.5194/acp-2017-765.

4. Jayakumar, A., Rajagopal, E. N., Boutle, I. A., George, J. P., Mohandas, S., Webster, S. and Aditi, S., An operational fog prediction system for Delhi using the $330 \mathrm{~m}$ Unified Model. Atmos. Sci. Lett., 2018, 19, e796; doi:10.1002/as1.796.

5. Patel, A., Katiyar, S. K., and Prasad, V., Performances evaluation of different open source DEM using differential global positioning system (DGPS). Egypt. J. Remote Sensing Space Sci., 2016, 19, 7-16; doi: http://dx.doi.org/10.1016/j.ejrs.2015.12.004.

6. Sethunadh, J., Jayakumar, A., Mohandas, S. A., Rajagopal, E. N. and Nagulu, A. S., Impact of Cartosat-1 orography on weather prediction in the high resolution NCMRWF Unified Model. J. Earth Syst. Sci., 2018 (accepted).

7. Nakoudi, K., Giannakaki E., Dandou, A., Tombrou, M. and Komppula, M., Planetary boundary Layer variability over New Delhi, India, during EUCAARI project, J. Atmos. Meas. Tech. (under review); doi: https://doi.org/10.5194/amt-2018-342.

8. Ferguson, A. S., Smoke dispersion prediction systems. In Smoke Management Guide (eds Hardy, C. et al.), National Wildlife Coordination Group, 2001, pp. 163-176.

Received 26 April 2018; revised accepted 14 December 2018

doi: $10.18520 / \mathrm{cs} / \mathrm{v} 116 / \mathrm{i} 5 / 816-822$

\section{Hydrocarbon generation potential of source rocks in Jaisalmer Basin, Rajasthan, India}

\author{
Rajesh Pandey $^{1, *}$, Dinesh Kumar ${ }^{1}$, A. S. Maurya ${ }^{1}$ \\ and Pooja Pandey ${ }^{2}$ \\ ${ }^{1}$ Department of Earth Sciences, Indian institute of Technology, \\ Roorkee 247 667, India \\ ${ }^{2}$ Department of Applied Sciences, PEC University, \\ Chandigarh 160 012, India
}

Geochemical and statistical analyses have been carried out for the evaluation of source rocks characteristics of Jaisalmer Basin, Rajasthan, India. The geochemical analysis includes pyrolysis data, total organic carbon, oxygen and hydrogen indices. The analysis suggests that Cretaceous source rocks are poor to fair with kerogen of types III-II and have the capability of generating gas and oil whereas the $\mathrm{Ju}$ rassic source rocks are poor with kerogen of type III and have the capability of generating gas. The Tertiary sources of rocks however have poor potential and are immature. The Jaisalmer Basin has gas-rich petroleum system, whereas the Baisakhi-Badesir and Pariwar sources have oil generation capability. The presence of higher concentration of $\mathrm{N}_{2}$ and $\mathrm{CO}_{2}$ in the gas suggests the over-maturation and residual accumulation of $\mathrm{N}_{2}$ and $\mathrm{CO}_{2}$ in the natural gases.

Keywords: Jaisalmer Basin, kerogen, pyrolysis data, source rock.

JAISALMER Basin in the eastern part of Indus Basin has commercial production of gas in India. The available data of four tectonic units, viz. Kishangarh shelf, JaisalmerMari high, Shahgarh low and Miajalar low are integrated. Maximum source rock data is available from JaisalmerMari High followed by Shahgarh low and Miajlar low, while sparse data is available from Kishangarh shelf. Jaisalmer-Mari High area is operated by M/s Oil and Natural Gas Corporation (ONGC), Shahgarh low is operated by $\mathrm{M} / \mathrm{s}$ Focus Energy Ltd. with ONGC as joint venture partner. Miajalar depression was operated by M/s Ente Nazionale Idrocarburi (ENI) and ONGC (now relinquished) and Kishangarh Shelf by Oil India Limited (OIL) independently.

In general, petroleum source rocks are fine-grained, organic-rich sediments that could either generate or have already generated and expelled significant amounts of petroleum $^{1}$. The source rock potential of the basin is to be evaluated initially for assessing hydrocarbon prospectivity of the basin in terms of oil and gas. The present paper has brought out source rock geochemistry and maturity based on a compilation of studies carried out by

\footnotetext{
*For correspondence. (e-mail: rajeshbhu20@gmail.com)
} 
various workers on total organic carbon (TOC), RockEval pyrolysis, vitrinite reflectance, isotopic data along with gas composition. The geochemical analysis includes pyrolysis data as total organic carbon (TOC \%), oxygen and hydrogen indices (OI, HI), generating source potential ( $S 1, S 2$ and $S 3$ ) and $T_{\max }$ (ref. 2).

Analysis of source rock data has been carried out for the important source rocks to estimate the potential of oil and gas generation from Jurassic (Lathi Formation) to Palaeocene (Sanu Formation) sequences. Based on detailed studies, source rocks within Baishakhi-Badesir and Pariwar formations appear to be the main for generation of gas and associated liquid hydrocarbons.

Jaisalmer Basin is a pericratonic basin in the northwestern part of India, known as western Rajasthan shelf ${ }^{3}$. The basin situated on the eastern shelf of part large Indus Basin and is characterized by thick sedimentary alternating sequences of clastics and carbonates. It is a late Palaeozoic-Mesozoic basin with gentle westerly slope (dip $3^{\circ}$ to $5^{\circ}$ ) and comprises rocks of Permian age which

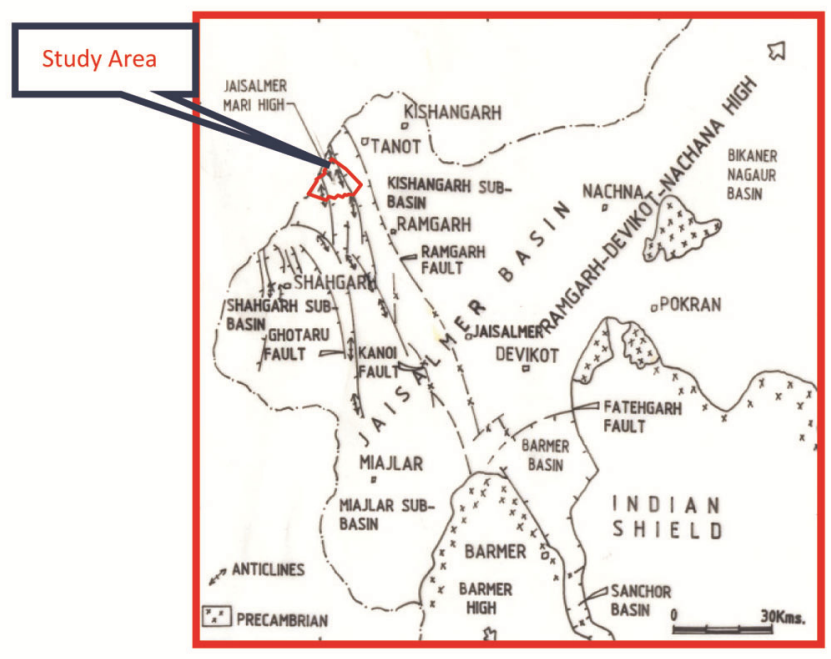

Figure 1. Structural elements of Jaisalmer Basin, Rajasthan, India.

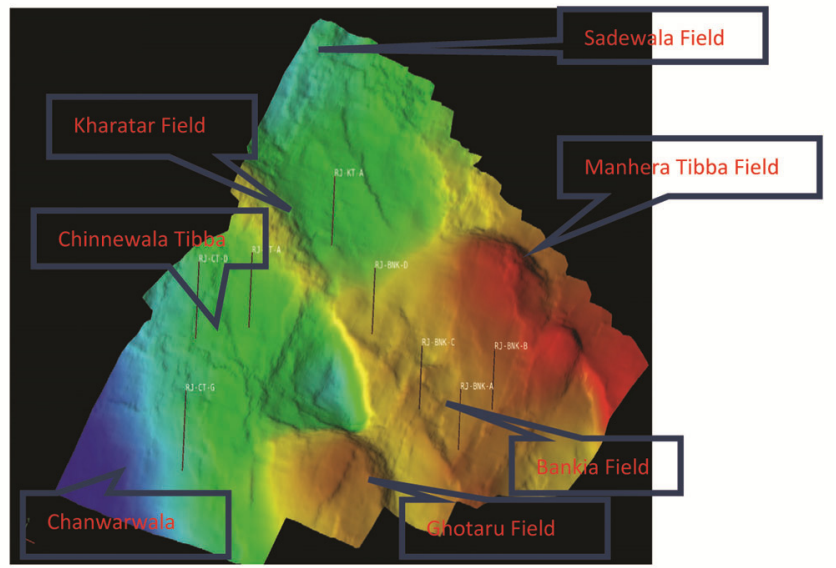

Figure 2. Spatial distribution of different gas fields in ONGC acreage. unconformably overlie the Proterozoic basement. The rocks of Tertiary and Mesozoic age are well exposed in this basin and represented mainly by limestone, shale, siltstone and sandstone ${ }^{4}$.

The basin covers an area of $45,000 \mathrm{sq}$. $\mathrm{km}$ and is contiguous with the gas-rich area of Middle Indus Basin of Pakistan. The Basin is subdivided into four tectonic blocks, viz. Kishangarh shelf, Jaisalmer-Mari high, Shahgarh low and Miajlar low. The NNW-SSE trending regional step-faulted Jaisalmer-Mari High zone occurs at the centre of the basin. The structural trend in the basin is regionally considered to be two-fold - a NNW-SSE trend corresponding to Dharwarian trend and a NE-SW trend parallel to the Aravalli range (Figure 1).

The stratigraphy of Jaisalmer Basin was first established by Blanford ${ }^{5}$, followed by Oldham ${ }^{6}$. Subsequently, the ONGC revised the stratigraphy of the basin (Table 1$)^{7}$.

A number of gas fields such as Manhera Tibba, Bankia, Ghotaru, Kharatar, Sadewala, Chinnewala Tibba and Bakhri Tibba have been established so far by ONGC in the Jaisalmer Basin (Figure 2). Currently gas is produced

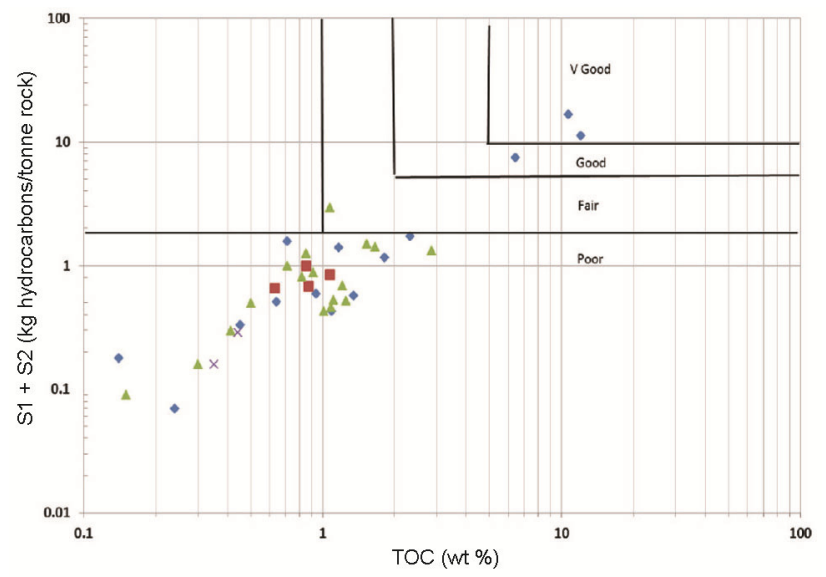

Figure 3. $S 1+S 2$ versus total organic carbon (TOC) plot for Lathi Formation.

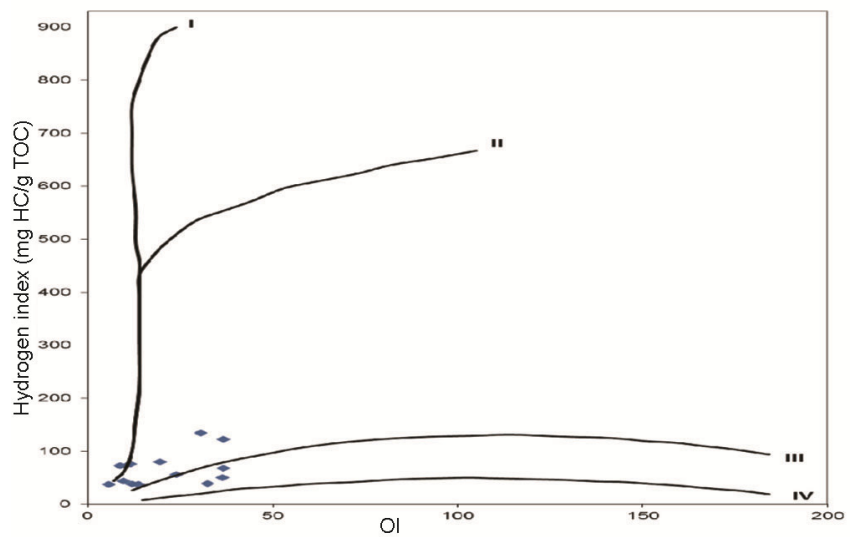

Figure 4. HI versus OI plot for Lathi Formation. 


\section{RESEARCH COMMUNICATIONS}

Table 1. Generalized stratigraphy of Jaisalmer Basin, Rajasthan

\begin{tabular}{|c|c|c|c|}
\hline Eon/era & Period/epoch & Formation & Lithology \\
\hline \multirow[t]{5}{*}{ Cenozoic } & Holocene & Wind-blown sand/alluvium & Loose sand and alluvial materials \\
\hline & Holocene to Pleistocene & Shumar & Dune sands, gravels with ferruginous nodules \\
\hline & Middle Eocene & Bandha & Foraminiferal limestone clayey at the base \\
\hline & Early Eocene & Khuiala & Shales with limestone beds and calcareous silt \\
\hline & Palaeocene & Sanu & Sandstone with minor clays \\
\hline \multirow[t]{7}{*}{ Mesozoic } & Late Cretaceous & Parh & Marls and arenaceous limestone \\
\hline & Middle-Early Cretaceous & Goru & Arenaceous limestones and calcareous sandstones \\
\hline & Early Cretaceous & Pariwar & Sandstone, shale, lignite \\
\hline & Late Jurassic & Baisakhi/Bhadesar & Sandstone and shale \\
\hline & Middle Jurassic & Jaisalmer & Limestone and Sandstone \\
\hline & Early Jurassic & Lathi & Sandstone, shale and lignite \\
\hline & Triassic & Sumarwali & Sandstone and clay stone \\
\hline \multirow[t]{2}{*}{ Palaeozoic } & Permian & Karampur & Shale and sandstone \\
\hline & Cambrian & Birmania & Sandstone and shale \\
\hline \multirow[t]{2}{*}{ Neoproterozoic } & Tonian/Cryogenian & Randha & Sandstone and shale \\
\hline & & Basement & Malani igneous suite/metamorphic basement \\
\hline
\end{tabular}

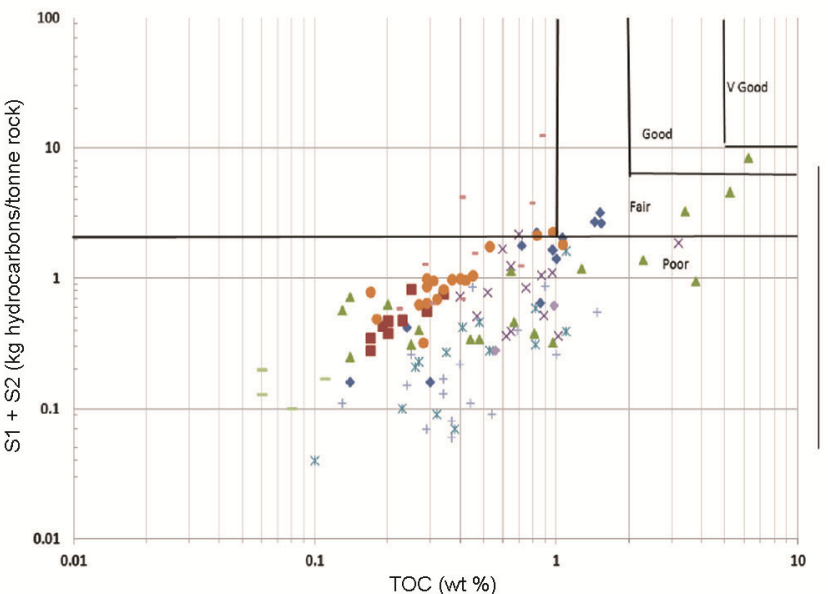

Figure 5. $S 1+S 2$ versus TOC plot for Jaisalmer Formation.

primarily from C2-C4 and B4 reservoirs of Khuiala Formation (Palaeocene to Lower Eocene) from Manhera Tibba Field. Besides, Sanu (Palaeocene), Lower Goru and Pariwar formations (Lower Cretaceous) have been found to be gas-bearing. Presence of minor oil within Lower Goru and Pariwar formations in Chinnewala Tibba, Ghotaru and Bankia fields has been proved during production testing of a few wells. Gas from Manhera Tibba field is supplied to M/s GAIL at GCS Gamnewala which in turn supplies to RRVNL at Ramgarh. Commercial gas is produced by M/s OIL in Tanot area, and in SGL field by $\mathrm{M} / \mathrm{s}$ Focus Energy Ltd towards the southwest.

There are a number of gas and oil fields in Middle Indus Basin, Pakistan and producing from Paleocene (Dunghan), Lower Eocene (Sui Main) and Middle Eocene (Habib Rahi) shelf carbonates. At deeper stratigraphic levels, production comes from subtle structural closures in the distal Cretaceous siliciclastic low stands of the

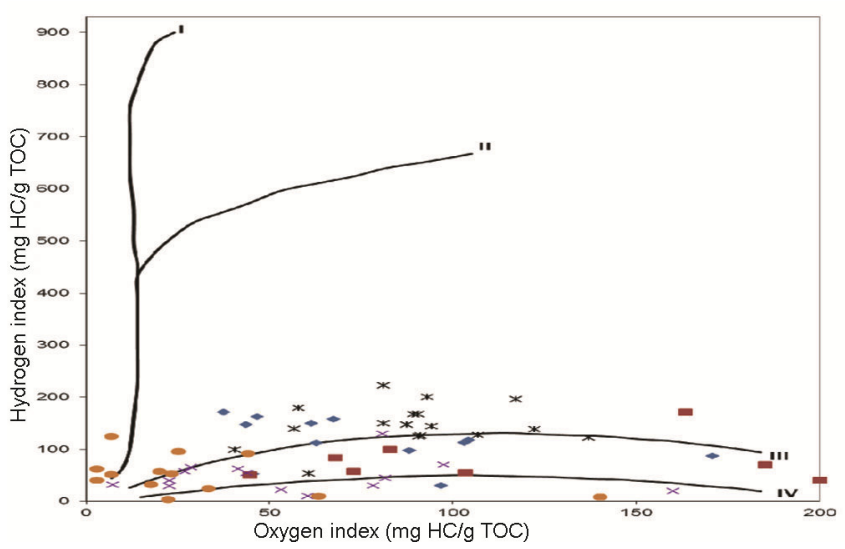

Figure 6. HI versus OI plot for Jaisalmer Formation.

Sembar and Lower Goru formations. Sui and Mari are important gas fields with commercial production whereas Lagheri and Khaskeli are the oil producing fields in Pakistan.

The composition of gas varies from one field to another also from deeper stratigraphic levels to shallower stratigraphic levels in the basin (Table 2).

In the deeper parts of basin in Pakistan, $\mathrm{N}_{2}$ and $\mathrm{CO}_{2} \%$ are observed to decrease in NW and western directions ${ }^{8}$.

The distribution, thickness, quality and thermal maturity of the organic matter are described for units of the drilled formations of the basin. Standard plots of the TOC and Rock-Eval pyrolysis data are used to understand source rock richness, quality, maturity and kerogen type. Original HI values for each formation and lithology are determined through the analysis. Where data density permits, maps of the present-day TOC and HI are prepared, for spatial variation in the amount and quality of 
RESEARCH COMMUNICATIONS

Table 2. Gas composition of different discovered gas fields on Jaisalmer Mari High

\begin{tabular}{|c|c|c|c|c|}
\hline Field & C1 (\%) & C2 (\%) & $\mathrm{CO}_{2}(\%)$ & $\mathrm{N}_{2}(\%)$ \\
\hline Manhera Tibba (Cretaceous reservoir) & $20-25$ & $0.6-0.8$ & $5-8$ & $60-70$ \\
\hline Manhera Tibba (Tertiary reservoir) & $40-50$ & $0.1-0.04$ & $1-5$ & $50-60$ \\
\hline Kharatar & $10-35$ & 0.05 & $5-10$ & $65-70$ \\
\hline Bankia & $20-30$ & $0.3-0.5$ & $2-10$ & $70-80$ \\
\hline Ghotaru & $20-30$ & $0.3-0.5$ & $5-10$ & $70-80$ \\
\hline Chinnewala Tibba & $60-70$ & $3-8$ & $2-8$ & $20-25$ \\
\hline Chanwarwala Dara & $60-80$ & 12.43 & 0.01 & 23.01 \\
\hline
\end{tabular}

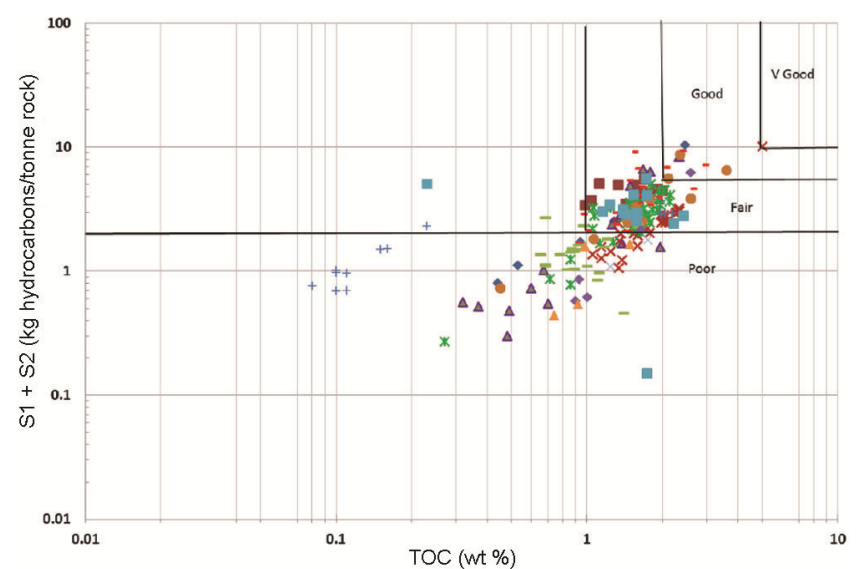

Figure 7. $S 1+S 2$ versus TOC plot for Baisakhi-Badesir Formation.

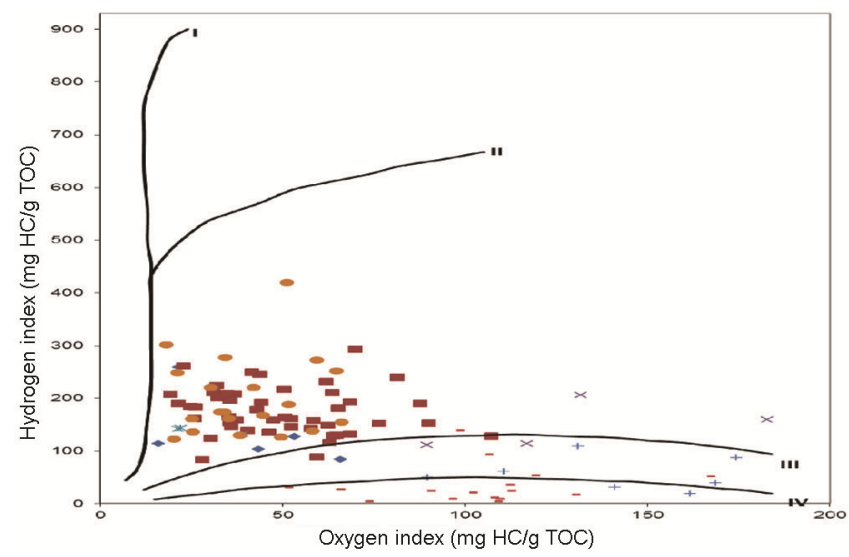

Figure 8. HI versus OI plot for Baisakhi-Badesir Formation.

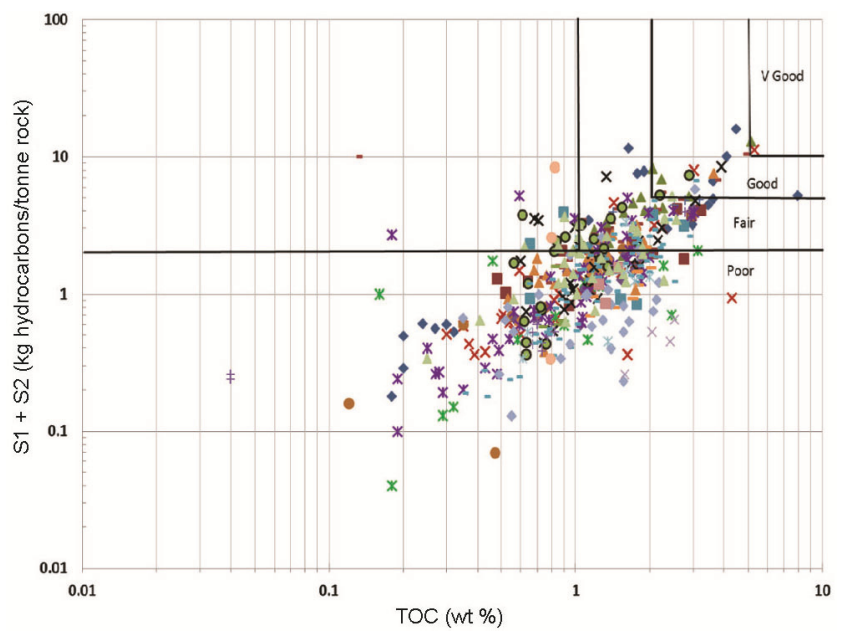

Figure 9. $S 1+S 2$ versus TOC plot for Pariwar Formation.

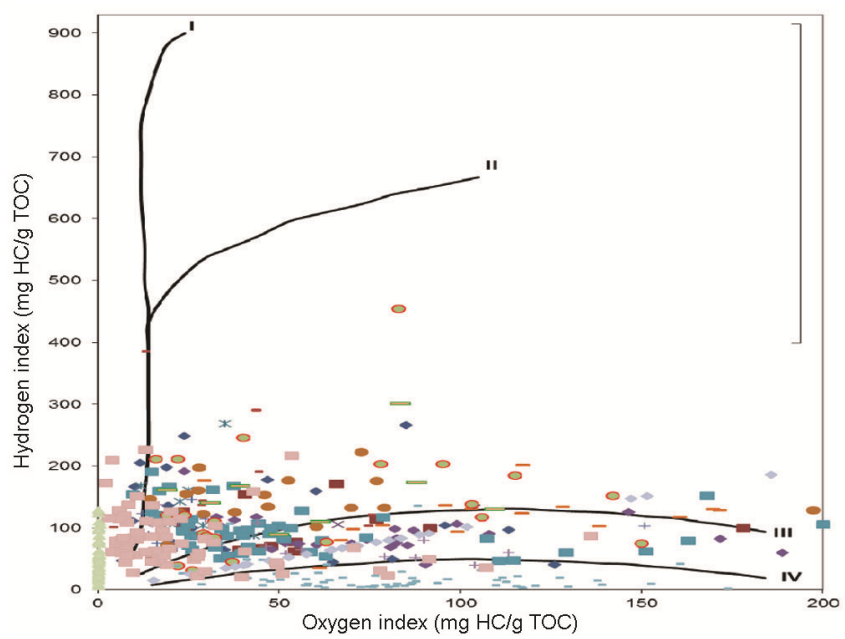

Figure 10. HI versus OI plot for Pariwar Formation.

tial (GP) is the sum of $S 1$ and $S 2$ values. According to Hunt $^{9}$, source rocks with GP $<2,2$ to 5,5 to 10 and $>10$ are considered to be poor, fair, good and very good respectively ${ }^{10}$. The kerogen type and maturity were determined based on pyrolysis data. Kerogen classification diagrams were prepared using the HI versus $T_{\max }$ plot $^{11}$.

The statistical analysis of Lathi Formation includes samples from four wells with TOC values and complete 


\section{RESEARCH COMMUNICATIONS}

Rock-Eval pyrolysis data. The majority of sample points are located in the eastern flank of the basin. The principal source rocks are shales, and analysis indicates that the formation has poor potential (Figure 3) with Type III source rock (Figure 4). The maximum TOC value for the formation is $1.2 \%$ and $\mathrm{HI}$ value is $<150 \mathrm{mg} \mathrm{HC} / \mathrm{g}$ TOC and $\mathrm{OI}<50 \mathrm{mg} \mathrm{HC} / \mathrm{g}$ TOC. Jaisalmer Formation has been penetrated in a few wells across the basin. Available samples were studied along with complete Rock-Eval pyrolysis data (very few drilled wells have gone up to Jaisalmer Formation and the samples from those wells have been used for geochemical analysis). The formation suggests fair to poor source rock potential (Figure 5) and dominantly Type III source rock (Figure 6). TOC value ranges between $0.1 \%$ and $1 \%$ and $\mathrm{HI}$ and $\mathrm{OI}$ values are up to $200 \mathrm{mg} \mathrm{HC} / \mathrm{g}$ TOC. TOC or HI maps were not are prepared due to the limited data. Similar analyses were carried out for Baisakhi-Badesir, Pariwar and Goru formations. The source rock potential plot $(S 1+S 2$ versus TOC) suggests these formations have fair to good

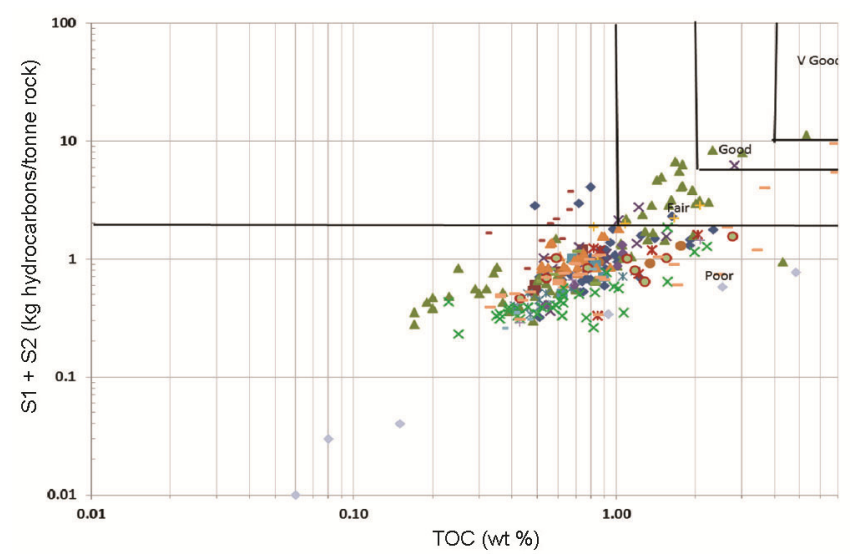

Figure 11. $S 1+S 2$ versus TOC plot for Goru Formation.

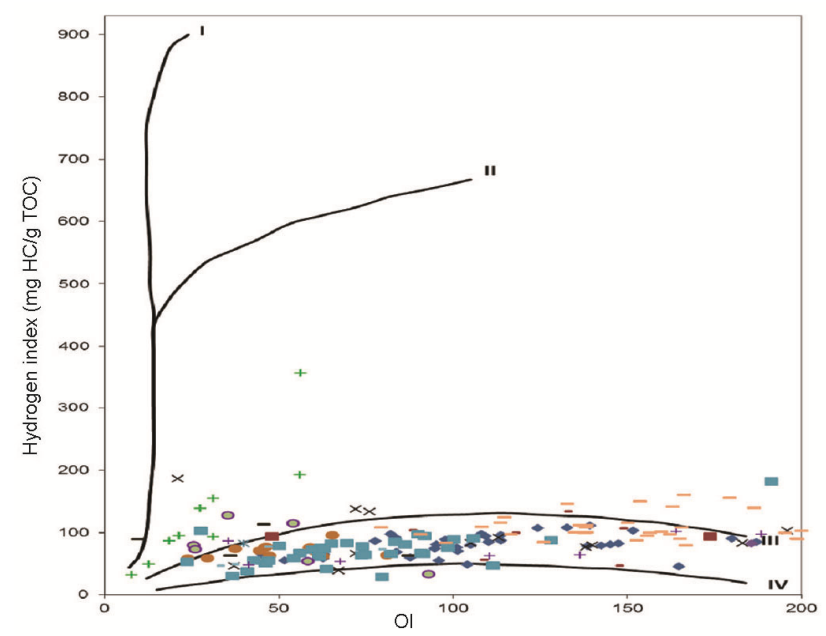

Figure 12. HI versus OI plot for Goru Formation. generation potential of hydrocarbons and dominantly type-II and type-III kerogen (Figures 7-12). Sanu Formation shows poor potential, type-III source rock.

TOC and HI maps were generated for best source rocks, i.e. Baisakhi-Badesir and Pariwar formations. The spatial distribution of Baisakhi-Badesir suggests that in Shahgarh and Miajalar sub-basin, the organic richness is good to very good (TOC 1.57-2.5\%) and the Hydrogen Index (HI) of the kerogen is in the range 163-204 mg $\mathrm{HC} / \mathrm{g}$ TOC, which is wet gas prone Type-III in the southern part. In Jaisalmer-Mari high the source rock data indicates good organic richness (TOC 1.63-5.3\%) and Type-II/III source rock indicates Oil and Gas prone kerogen (HI-240-260 mg HC/g TOC). The HI is found to be increasing from Manhera Tibba to Sadewala and Manhera Tibba to Shahgarh. Towards the south-western margin, best source rock is found in Shagarh low with high TOC and HI values.

The spatial distribution of TOC in Pariwar Formation suggests maximum TOC value at Jaisalmer Mari High near Kharatar Gas Field and minimum TOC value in Shahgarh depression. HI value decreases from SW to NE direction. Espitalie et al. ${ }^{11}$ reported that oil generation from source rocks began at $T_{\max }=435-465^{\circ} \mathrm{C}$ and production index 'PI' between 0.2 and 0.4 . The source rock analysis indicates that Baisakhi-Badesir and Pariwar formations have capacity to generate liquid hydrocarbons (Figures 13 and 14).

Pariwar and Basisakhi-Badesir formations have TypeII kerogen along with Type-III and indicate the presence of gas rich source potential with potential generation of oil. The shales of Baisakhi-Bhadesir and Pariwar formations as well as shales of Lower Goru Formation have been identified as major source rock units. Source rock richness increases towards west and south-west along the basinal slope. Top of oil window in the basin, ranges

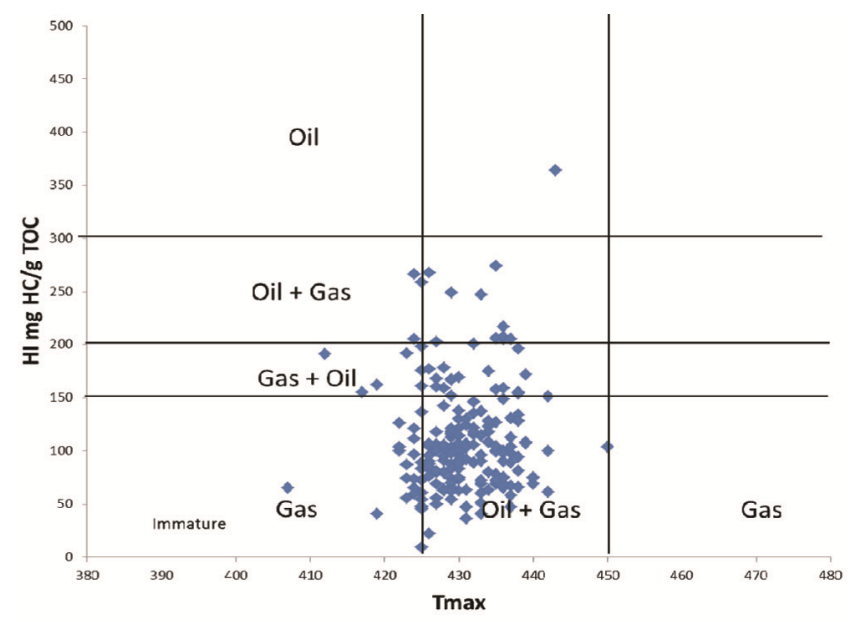

Figure 13. $T_{\max }$ versus HI plot of Pariwar Formation to show generation capabilities of source rock, Jaisalmer Basin. 


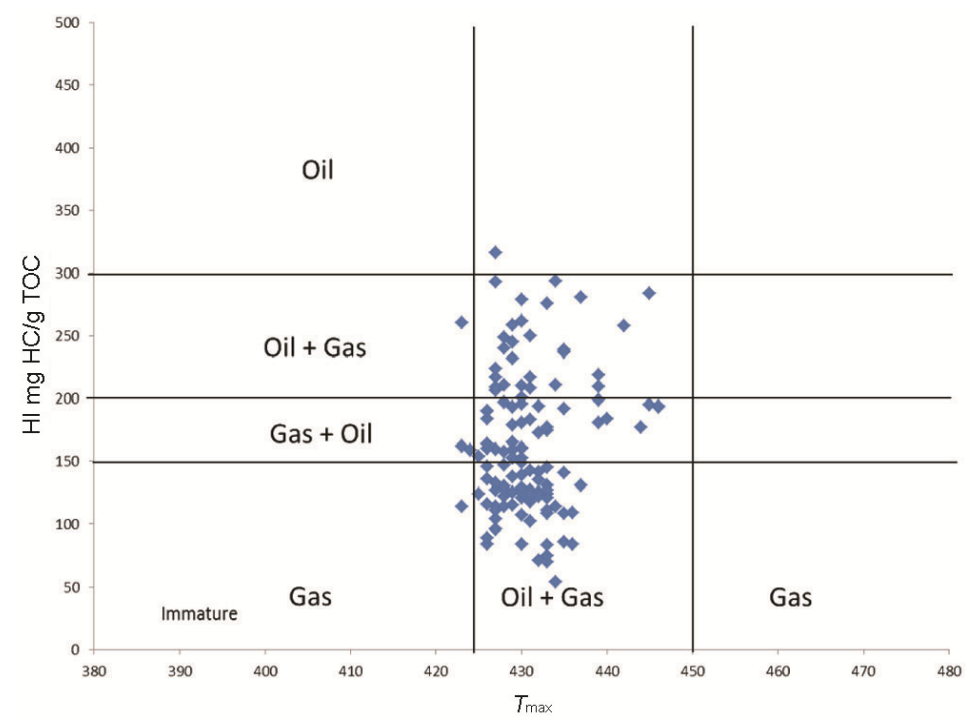

Figure 14. $T_{\max }$ versus HI plot of Baisakhi-Badesir Formation to show generation capabilities of source rock, Jaisalmer Basin.

from 1950 to $2800 \mathrm{~m}$ in consonance with the basinal geometry where Mesozoic sequences have attained threshold to adequate thermal maturation. The concentration of $\mathrm{CO}_{2}$ in the gases of the study area is highly variable ranging from $0.73 \%$ to $10 \%$ in Ghotaru Field, $\sim 70 \%$ in Kharatar Field. Similarly, the concentration of $\mathrm{N}_{2}$ ranges from $33 \%$ to $62 \%$ in Kharatar, $68 \%$ to $75 \%$ in Bankia and up to $65.21 \%$ to $81.0 \%$ in Ghotaru Field. Since mantlederived helium has not been observed, presence of $\mathrm{CO}_{2}$ and $\mathrm{N}_{2}$ is inferred to be of non-mantle origin. Such higher percentages of $\mathrm{CO}_{2}$ and $\mathrm{N}_{2}$ are assumed to be because of over-maturation $^{12}$.

The source rock maturity is high, but accumulations are relatively small, which suggests early escape of generated hydrocarbons. This is consistent with the late Pliocene trap formation and explains the high $\mathrm{N}_{2}$ concentrations. Further, $\mathrm{N}_{2}$ is considered to have evolved as an end-product of organic maturation. It is also inferred that identified source rock units of the basin might have generated and expelled hydrocarbons during Late Eocene due to lack of suitable entrapment condition to accommodate the discharge from these source beds while some may have escaped through the regional faults/erosional surfaces.

1. Peters, K. E., Guidelines for evaluating petroleum source rocks using programmed pyrolysis. Am. Assoc. Petrol. Geol. Bull., 1986, 70, 318-329.

2. Nady, M. M. E., Ramadan, F. S., Hammad, M. M. and Lotfy, N. M., Evaluation of organic matters, hydrocarbon potential and thermal maturity of source rocks based on geochemical and statistical methods: case study of source rocks in Ras Gharib oilfield, central Gulf of Suez, Egypt. Egypt. J. Petrol., 2015, 24, 203-211.

3. Singh, N. P., Mesozoic lithostratigraphy of the Jaisalmer Basin, Rajasthan. J. Palaeontol. Soc. India, 2006, 51(2), 1-25.

4. Dasgupta, S. K. and Chandra, M., Tectonic elements of western Rajasthan Shelf and their stratigraphy. In Proceeding of the Gol- den Jubilee Symposium, Geological, Mining and Metallurgical Society of India, 1978.

5. Blanford, W. T., On the physical geography of the Great Indian desert with special reference to the former exixtance of the sea in the Indus valley and on the origin and mode of the formation of the sand hills. J. Asiat. Soc. Bengal, 1876, 45(2), 86-103.

6. Oldham, R. D., Preliminary notes on the geology of North Jaisalmer. Rec. Geol. Soc. India, 1886, 19(3).

7. Mishra, P. C. and Singh, N. P., Western Rajasthan Basin, Lithostratigraphy of Indian Petroliferous Basins, Documents-II, KDMIPE, ONGC, Dehradun, 1993.

8. Tainsh, H. R., Stringer, K. C. and Azad, J., Major gas field of Western Pakistan. AAPG Bull., 1959, 43(ii), 2675-2700.

9. Hunt, J. M., Petroleum Geochemistry and Geology, Freeman, New York, 1996, 2nd edn, p. 74.

10. Waples, D. W., Geochemistry in petroleum exploration: International Human Resources Development Corporation, Boston, USA, 1985, p. 232.

11. Espitalie, J., Deroo, G. and Marquis, F., Rock-Eval pyrolysis and its application. Rev. Inst. Fr. Petrol., 1985, 72.

12. Klein, J. and Jimtgen, W., Studies in the emission of elemental nitrogen from coal of different rank and its release under geochemical conditions. Adv.Org. Geochem., 1972, 647-656.

ACKNOWLEDGEMENTS. We are grateful to the management of ONGC for giving permission to publish this work. We also acknowledge GGM-Basin Manager, Frontier Basin, ONGC, Dehradun, for providing an opportunity and all necessary facilities to prepare this paper. We also acknowledge the support given by all colleagues in the group. The views expressed in the paper are those of the authors and not the affiliated organization.

Received 26 July 2017; revised accepted 25 September 2018

doi: $10.18520 / \mathrm{cs} / \mathrm{v} 116 / \mathrm{i} 5 / 822-827$ 